\title{
地域熱供給プラント運用評価のための動特性シミュレータの開発
}

船津 徹也 ${ }^{* 1}$

\section{Development of a dynamic simulator for the evaluation of DHC plant operation}

\author{
Tetsuya FUNATSU*1 \\ ${ }^{* 1}$ Toshiba Corporation \\ 72-34 Horikawa-chou, Saiwai-ku, Kawasaki-shi, Kanagawa 212-8585, Japan
}

Received: 27 December 2016; Revised: 16 April 2017; Accepted: 21 July 2017

\begin{abstract}
The energy consumption of air conditioning for the business and home use is about $9 \%$ of the total energy consumption in Japan. It is effective for the energy conservation to reduce the consumption. The reduction of air conditioning energy has been promoted mainly by the development of high efficiency equipment. For further reduction, the optimum control of the air conditioning together with the heat supply equipment will make a contribution. A dynamic simulation is expected to be one of the tools for the optimization. The paper presents development of a dynamic simulator for the purpose of the evaluation of district heat and cool (DHC) plant operation and control. A double effect absorption chiller model and a cooling tower model are developed for the simulator. The developed chiller model is based on the dynamic approach which accommodates the heat capacity of the equipment and the sensible and latent heat of the internal liquid to evaluate the energy loss derived from the time delay of the startup. The steam system model which consists of the steam header, pipes and valves has been developed for the study of the impact by the mutual steam accommodation in the neat future with the neighboring combined heat and power plant. The boundary of the simulator is the equipment and system inside the DHC plant and the flow pipes to the district demand is not accommodated. The outputs of developed models suitably describe the equipment test data. These models are applied to the developed DHC plant dynamic simulator and the results of the simulation show good accordance with the DHC plant data. The simulator is confirmed to be a useful tool for the study of optimum DHC plant operation and control. Further, it can be useful for the evaluation of the impact on the DHC plant in the plant expansion and modification or in the plant connection and cooperation with the neighboring plant.
\end{abstract}

Key words : DHC plant dynamic simulator, Double effect absorption chiller model, Cooling tower model

\section{1. 緒言}

日本で消費されるエネルギのうち，業務部門と家庭部門を合わせた民生部門が占める割合は全体の約 3 分の 1 を占めており，このうちの約 3 割は冷暖房等の空調設備で消費されている（経済産業省，2016）。これは日本の消 費エネルギの約 1 割に相当するため, 空調設備の消費エネルギ削減は日本の省エネルギや環境負荷削減に対して 一定の効果をもたらすことが期待される.さらにこの消費エネルギ削減は，都市部のヒートアイランド現象の主 要因の一つである空調設備からの排熱を削減することに繋がるため, 空調負荷そのものの削減にも効果があると 考えられる.

空調設備での消費ネルギ削減は主に機器の高効率化により推進されてきたが，一方で空調システムの最適化に よる省エネルギも検討されてきた。例えばオフィスビル等ではビルの性能向上や省エネルギを目的に，設備設計 の最適化，設備完成後の省エネルギの維持・管理を行うコミッショニングが提案されている（中原，2001）。この ようなコミッショニングは，従来は負荷側であるビル空調システムの最適化に限られていたが，最近では熱源プ ラントを含めた全体最適化も計画されている。全体最適化においては熱源プラントと空調システムとを連係し， 運用状況に応じた運転・制御の調整を行う必要があり，このための動的なシステムシミュレーションが重要とな

No.16-00583 [DOI:10.1299/transjsme.16-00583], J-STAGE Advance Publication date : 4 August, 2017

*1 正員, (株) 東芝（干212-8585＼cjkstart神奈川県川崎市幸区堀河町 72-34）

E-mail of corresponding author: tetsuya.funatsu@toshiba.co.jp 
っている.

熱源機器の動特性モデルに関しては, 斎藤らにより蒸気式二重効用吸収式冷凍機の動特性解析 (斎藤他, 1997a) や起動特性解析（斎藤他，1997b）が報告されている. 吸収式冷凍機の詳細な動特性を解明することを目的に吸収 式冷凍機内部の詳細モデルを構築し, 実験装置の内部状態量を計測することで伝熱特性を解明し精度の高いモデ ルを提案している. Kohlenbach らは単効用吸収式冷凍機の詳細な動特性モデルを開発しモデル出力と実機データ との比較や, 容器の熱容量や吸収器一再生器間の溶液輸送遅れに対する感度解析を報告している（Kohlenbach and Ziegler, 2008a, 2008b)．モデルの動特性出力は実験データと精度良く一致しているが，モデルの入力值には設計值 を含む多数の内部パラメータを必要としている. Evola らは太陽熱を利用した吸収式冷凍機の動特性モデルを開 発し, 実機データとの比較を行っている（Evola et al., 2013）。ただし比較は冷水・冷却水温度など吸収式冷凍機外 部の温度応答のみで, 実機の内部データは計測されていない. モデルの内部パラメータとして過去の様々な研究 で報告された值が引用されており, 前述の Kohlenbach らの報告を参照したパラメータ確認試験がなされている. このほか, Xu らは前述の Evola らのモデル出力を参照值とし, これに精度よく一致する動特性モデルを報告（Xu et al., 2016)，Marc らは太陽熱を利用した吸収式冷凍機の動特性モデルを開発し試験データとの比較を報告（Marc et al., 2013)，Matsushima らは動特性モデルに対してオブジェクト指向によるプログラミングを行い，新しい内部 溶液流量計算のアルゴリズムを提案している（Matsushima et al., 2010）。以上の研究ではいずれも実機の内部状態 を計測し，そのデータに基づきモデルの内部パラメータを調整することで精度の高いモデルが報告されている. この場合, 実機の条件が変わるたびに煩雑なパラメータ調査, 調整を行う必要が生じる可能性がある. 本研究で は, 冷凍機内部の状態量をブラックボックスとし, 吸収式冷凍機製造メーカから与えられるユーザマニュアル等 の情報およびユーザが実際に機器を運転して得られる機器からの出力情報のみに基づいて精度の高い動特性モデ ルを構築する。ユーザ情報のみに基づくモデル構築のため詳細な入力值やパラメータ調整は必要とせず汎用性に 優れていると考えられる.

一方, 地域熱供給プラントから需要家への熱供給に関する動特性シミュレーションは Casetta らにより報告され ている (Casetta et al., 2015). Casetta らはターボ冷凍機 7 台と熱交換器 3 台からなるプラントと需要家への熱供給 配管網をモデル化し, 動特性シミュレーションによりその有効性を検証している. しかし報告されているターボ 冷凍機モデルは冷却水温度，冷水温度および負荷率に基づく静特性ベースの関数であるため，例えば起動による 応答遅れやエネルギ損失等は正確に表されていない可能性がある. また吸収式冷凍機のように，ボイラや蒸気流 量制御など大きな応答遅れを伴う複雑なシステムが必要な機器では大きな誤差を生ずる可能性がある.この他に も，地域熱供給プラントと個別プラントとの省エネルギ性を検証したシミュレーション結果や (Shimoda et al., 2005), ガスエンジン駆動の冷凍機を備えた地域熱供給プラントの省エネルギ性に関するシミュレーション結果

(Tanaka and Shimizu, 2011）等が報告されているが，いずれの報告でも熱源機器モデルは簡単な静特性関数で表 されている.

本研究では, 地域熱供給プラントの運転, 制御, システムに関して, 省エネルギのための改善手法の構築やそ の効果の事前確認等を目的として熱源プラント動特性シミュレータを開発した. 熱源機器モデルはモデル出力ヘ の影響が小さな因子を省略することで簡易なモデルとする一方, 起動時の応答遅れやそれによるエネルギ損失等 を正確に評価できるよう機器の熱容量や内部流体の蒸発, 凝縮等を考慮した動特性ベースのモデルとした. さら に近い将来近隣施設に導入されるコージェネレーション設備との蒸気融通が計画されており, それによる圧力変 動やプラントへの影響を解析できるようボイラから蒸気ヘッダを介して吸収式冷凍機や温水熱交換器に至る蒸気 系統をモデル化した。 なお，モデル化の範囲は地域熱供給プラント機器およびシステムであり，プラントから需 要家への冷熱，温熱供給配管等はシミュレータの対象外としている. 著者はこれまで熱源機器モデルを開発し報 告を行ってきた（高木他，2004）が，今回，開発した熱源機器モデルのうち吸収式冷凍機および冷却塔について， モデル出力と実機の運転データとの比較によるモデルの検証を行った. その結果モデル出力が運転データを良く 表していることを確認した. またこの熱源機器モデルを適用して地域熱供給プラントシミュレータを構築した. 夏期の代表的なプラント負荷に対するシミュレーションを行い, プラントでのガス消費量, 電力消費量, 冷却水 への補給水供給量がプラント運転データと良く一致していることを確認した。開発したシミュレータは，熱源機 器の起動, 停止を含めた動特性を精度良く表すことができるため, プラントの運用改善や制御変更によるガス, 電気, 水等消費量への影響を事前に検討し, 環境や負荷需要等の運転条件に最適なプラント運転方法を確認する 
ことができる. また，将来の熱源機器増設や合理化，コージェネレーションなど近隣設備との接続や合理化運用 などプラント改修時の健全性を動特性検討により評価することができる.

\section{2. 記号}
A：伝熱面積
$\left[\mathrm{m}^{2}\right]$
$C$ : 熱容量
$[\mathrm{kJ} / \mathrm{C} \mathrm{C}]$
$C p:$ 比熱
$\left[\mathrm{kJ} /(\mathrm{kg} / \mathrm{s}) /{ }^{\circ} \mathrm{C}\right]$
$C v ：$ 弁容量
$[-]$
$D$ : 拡散係数
$\left[\mathrm{m}^{2} / \mathrm{s}\right]$
$G$ ：質量流量
$[\mathrm{kg} / \mathrm{s}]$
$H ： \quad$ 比エンタルピ
$[\mathrm{kJ} / \mathrm{kg}]$
$K$ : 物質伝達率
$\left[\mathrm{kg} / \mathrm{kPa} / \mathrm{m}^{2} / \mathrm{s}\right]$
$K_{a}$ : エンタルピ基準総括熱伝達係数
$L$ : 拡散距離
[m]
$P$ : 圧力
$[\mathrm{kPa}]$
$Q$ ：冷凍機外部との交換熱量 $[\mathrm{kW}]$
$R$ ：配管抵抗
$\left[\mathrm{s}(\mathrm{kPa})^{1 / 2} / \mathrm{m}^{3 / 2}\right]$
$R H ： \quad$ 相対湿度
[\%]
$S: \quad$ 断面積
$\left[\mathrm{m}^{2}\right]$
$T$ : 温度
$\left[{ }^{\circ} \mathrm{C}\right]$
$V: \quad$ 容積
$\left[\mathrm{m}^{3}\right]$
$W$ : 質量
[kg]
$X ：$ 臭化リチウム濃度（質量比） [-]
$\Phi: \quad$ 温度効率
[-]
$[\mathrm{kW} /(\mathrm{kJ} / \mathrm{kg})]$
$d v_{s} / d P: \quad$ 飽和蒸気の圧力変化に対寸る比容積の変化率 $\left[\mathrm{m}^{3} / \mathrm{kg} / \mathrm{kPa}\right]$
$k:$ 比例定数 $[\mathrm{kg} / \mathrm{s} / \mathrm{kPa}]$
$\rho: \quad$ 溶液中の成分密度 $\left[\mathrm{kg} / \mathrm{m}^{3}\right]$
$\rho_{s}$ : 飽和蒸気密度 $\left[\mathrm{kg} / \mathrm{m}^{3}\right]$
$\nu_{s}$ : 飽和蒸気比容積 $\left[\mathrm{m}^{3} / \mathrm{kg}\right]$
添字
$L B, \mathrm{H}_{2} \mathrm{O}$ ：臭化リチウム $(\mathrm{LiBr})$, 冷媒水または冷媒蒸気
$g, S, W$ : 空気, 水蒸気, 水
$i, o:$ 入口, 出口

\section{3. 熱源機器モデルの概要}

熱源機器モデルとして, 地域熱供給プラント性能を決める主要な機器である吸収式冷凍機と, その冷却水温度 を制御する冷却塔について以下に示す，なお，ターボ冷凍機のモデルについては高木らによる空調システム評価 のための熱原器モデルの開発（高木他, 2004), ボイラおよび温水熱交換器については Funatsu らによるコンバイ ンドサイクル発電プラントの動特性シミュレーション（Funatsu et al., 1999）にてそれぞれ報告されている.

\section{$3 \cdot 1$ 吸収式冷凍機モデル}

吸収式冷凍機の概要を図 1 に示寸，図は水一臭化リチウム（LiBr）を媒体とした二重効用吸収式冷凍機で，高 温再生器 $r 1$, 低温再生器 $r 2$, 凝縮器 $c$, 蒸発器 $v$, 吸収器 $a$, 熱交換器 $h e x て ゙$ 構成される. 高温再生器では $\operatorname{LiBr}$ 稀溶液が外部からの蒸気によって加熱され, 冷媒蒸気と $\mathrm{LiBr}$ 中濃度溶液とに分離される. LiBr 中濃度溶液は熱 
交換器で泠却された後, 低温再生器へ流入し, 高温再生器からの冷媒蒸気による加熱により, さらに冷媒蒸気と $\mathrm{LiBr}$ 高濃度溶液とに分離される. 高温再生器および低温再生器からの冷媒蒸気は凝縮器で外部からの冷却水によ り冷却され凝縮水となる。凝縮水は蒸発器に流入すると蒸発して再び冷媒蒸気となり, このとき外部からの戻り 冷水を冷却して供給冷水を製造寸る. 蒸発器の冷媒蒸気は, 吸収器で低温再生器から流入した LiBr 高濃度溶液に 吸収されて LiBr 稀溶液となり高温再生器へ送られる. 以上のサイクルを水一臭化リチウム水溶液デューリング線 図で表すと図 2 となる. 図中の実線は LiBr 溶液, 破線は冷媒蒸気のサイクルを表している (高田, 吉川, 2004).

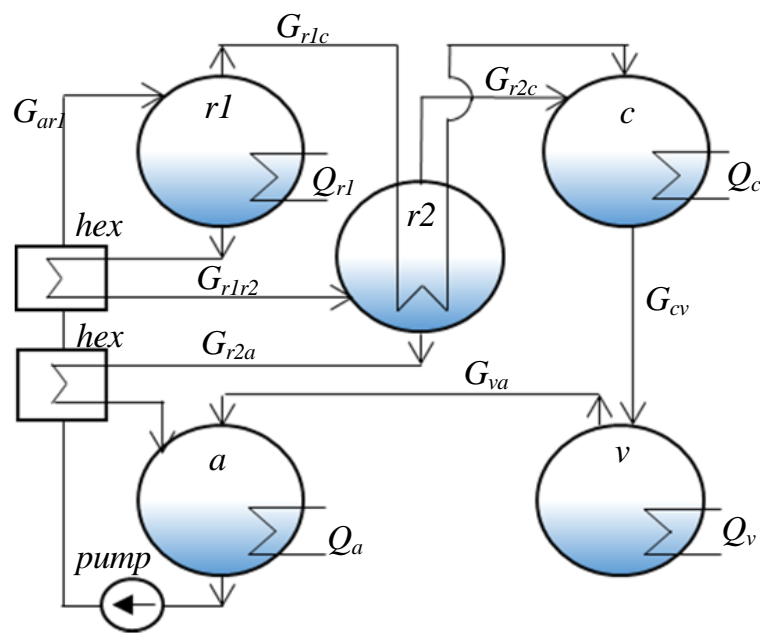

Fig.1 Flow diagram of double effect absorption chiller.

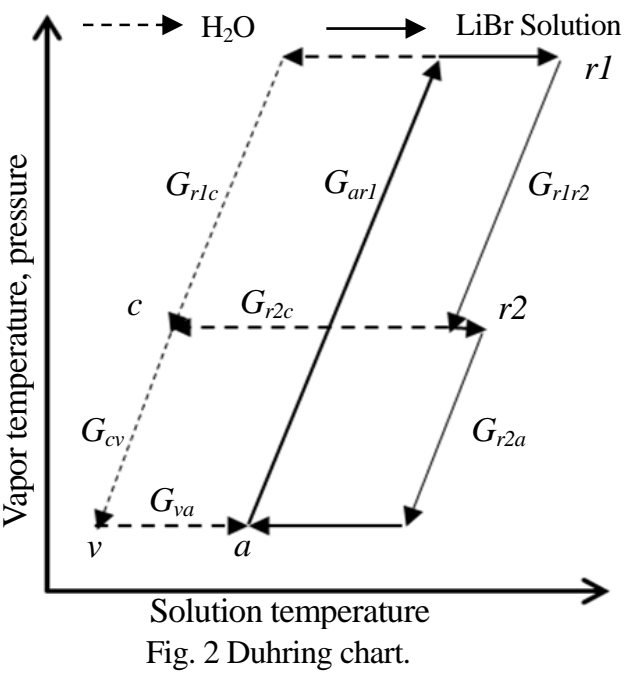

Fig. 2 Duhring chart.

吸収式冷凍機モデルは, 上記サイクルに基づき高温・低温再生器, 凝縮器, 蒸発器, 吸収器での熱収支, 物質 収支から泠水出口温度, 冷却水出口温度, 蒸気消費量を計算し, 動的応答を出力する. 高温・低温再生器, 凝縮 器, 蒸発器, 吸収器での熱収支, 物質収支を式(1) 式(22)に示す. なお質量流量 $G$ の添え字の順番は流量の方向 を示しており, 例えば高温再生器 $r 1$ から凝縮器 $c$ への流量は $G_{r 1 c}$ として表されている. また冷媒蒸気や LiBr 溶 液の物性值は, 1999 日本機械学会蒸気表（日本機械学会, 1999）および熱物性ハンドブック（日本熱物性学会, 2008）のデータに基づく関数により計算される.

高温再生器熱収支：

$$
C_{r_{1}} \frac{d T_{r_{1}}}{d t}=Q_{r 1}-G_{a r_{1}} H_{r_{1} i}-G_{r_{1} r_{2}} H_{r_{1}}-G_{r_{1} c} H_{r_{1} c}
$$

高温再生器物質収支：

$$
\begin{aligned}
& \frac{d W_{H_{2} O r_{1}}}{d t}=\left(1-X_{a}\right) G_{a r_{1}}-\left(1-X_{r_{1}}\right) G_{r_{1} r_{2}}-G_{r_{1} c} \\
& \frac{d W_{L B r_{1}}}{d t}=X_{a} G_{a r_{1}}-X_{r_{1}} G_{r_{1} r_{2}} \\
& X_{r_{1}}=\frac{W_{L B r_{1}}}{\left(W_{H_{2}} O r_{1}+W_{L B r_{1}}\right)}
\end{aligned}
$$

低温再生器熱収支：

$$
C_{r_{2}} \frac{d T_{r_{2}}}{d t}=G_{r_{1} c}\left(H_{r_{1} c}-H_{c i}\right)+G_{r 1 r 2} H_{r 2 i}-G_{r_{2} a} H_{r_{2}}-G_{r_{2} c} H_{r_{2} c}
$$

低温再生器物質収支：

$$
\begin{aligned}
& \frac{d W_{H_{2} O r_{2}}}{d t}=\left(1-X_{r_{1}}\right) G_{r_{1} r_{2}}-\left(1-X_{r_{2}}\right) G_{r_{1} a}-G_{r_{2} c} \\
& \frac{d W_{L B r_{2}}}{d t}=X_{r_{1}} G_{r_{1} r_{2}}-X_{r_{2}} G_{r_{2} a}
\end{aligned}
$$




$$
X_{r_{2}}=\frac{W_{L B r_{2}}}{\left(W_{H_{2} O r_{2}}+W_{L B r_{2}}\right)}
$$

凝縮器熱収支:

$$
C_{c} \frac{d T_{c}}{d t}=G_{r_{1} c} H_{c i}+G_{r_{2} c} H_{r_{2} c}-G_{c v} H_{c}-Q_{c}
$$

凝縮器物質収支：

$$
\frac{d W_{H_{2} O c}}{d t}=G_{r_{1} c}+G_{r_{2} c}-G_{c v}
$$

蒸発器熱収支：

$$
C_{v} \frac{d T_{v}}{d t}=Q_{v}+G_{c v} H_{c}-G_{v a} H_{v a}
$$

蒸発器物質収支：

$$
\frac{d W_{H_{2} O v}}{d t}=G_{c v}-G_{v a}
$$

泠媒蒸気流量 $G_{v a}$ は， $\mathrm{LiBr}$ 溶液による水蒸気の吸収として次式で表される（藤田，飛原，1997）.

$$
G_{v a}=-S_{v a} D_{v a} \frac{\rho_{\mathrm{H}_{2} \mathrm{Oa}}-\rho_{\mathrm{H}_{2} \mathrm{Ov}}}{L_{v a}}
$$

吸収器熱収支：

$$
C_{a} \frac{d T_{a}}{d t}=G_{r_{2} a} H_{a i}+G_{v a} H_{v a}-G_{a r_{1}} H_{a}-Q_{a}
$$

吸収器物質収支：

$$
\begin{aligned}
& \frac{d W_{H_{2} O a}}{d t}=\left(1-X_{r_{2}}\right) G_{r_{2} a}+G_{v a}-\left(1-X_{a}\right) G_{a r_{1}} \\
& \frac{d W_{L B a}}{d t}=X_{r_{2}} G_{r_{2} a}-X_{a} G_{a r_{1}} \\
& X_{a}=\frac{W_{L B a}}{\left(W_{\left.H_{2} O a+W_{L B a}\right)}\right.}
\end{aligned}
$$

高温・低温再生器, 凝縮器, 蒸発器, 吸収器での外部との熱交換量 $Q$ は次式で表される. ここで, $T$ は容器に 溜まった液体の温度, $G$ は容器中の液体と熱交換する流体の質量流量, $T_{i}, T_{o}, H_{i}, H_{o}$ は, この流体の入口, 出 口温度，および入口，出口比エンタルピである.

$$
\begin{aligned}
& T_{o}=T-\emptyset\left(T-T_{i}\right) \\
& Q=G C p_{w}\left(T_{o}-T_{i}\right) \text { あるいは, } Q=G\left(H_{o}-H_{i}\right)
\end{aligned}
$$

吸収式冷凍機に供給される飽和蒸気の圧力, 流量は式(20)から式(22)で表される. 圧力は各ボイラからの蒸気が 合流する蒸気へッダおよび蒸気流量制御弁上流を計算ノードとし，そのノードに対して流入，流出する蒸気流量 から式(20)により計算される，圧力ノード間の配管を流れる流量は式(21)により，蒸気流量制御弁を流れる流量は 式(22)により計算される. なお式(22)は弁出入口差圧が弁入口圧力 $P_{i}$ の $1 / 2$ 以上を仮定したときの飽和蒸気流量を 表した式である. Cv は蒸気流量制御弁開度の関数で, 吸収式冷凍機出口冷水温度が $7^{\circ} \mathrm{C}$ となるように比例積分制 御（PI 制御）により決定される.

$$
\frac{d P}{d t}=\frac{v_{s}}{\rho_{s} V\left(d v_{s} / d P\right)}\left(G_{i}-G_{o}\right)
$$




$$
\begin{aligned}
& G=\frac{1}{R} \sqrt{\rho_{s}\left(P_{i}-P_{o}\right)} \\
& G=k C v P_{i}
\end{aligned}
$$

上記吸収式冷凍機モデルの主要なパラメータを表 1 に纏める. 各パラメータは，まず吸収式冷凍機モデルの出 力がメーカ予想性能と一致するように調整され, さらに実機データとの比較により誤差が最小となるよう調整さ れたものである，実機データは，地域熱供給プラントで商業運転中の吸収式冷凍機の 1 台に対して起動や需要家 への冷熱供給時に温度調整，負荷調整を行い収集されたものである. 表 1 によれば温度効率は起動時を含めて一 定值で与えられている。 これは, 凝縮器, 蒸発器, 吸収器においては, 起動時にはすでに冷水, 冷却水とも定格 付近の流量が確立していること, また高温・低温再生器においては定格運転時の温度効率が非常に高く調整され ていることから，起動時低蒸気流量域での温度効率変化は殆ど無視しうると考えられるためである.

Table 1 Parameters of absorption chiller model

\begin{tabular}{l|c}
\hline \multicolumn{1}{c|}{ Parameters } & Value \\
\hline Heat exchanger effectiveness of high temperature re-generator & 0.99 \\
\hline Heat exchanger effectiveness of low temperature re-generator & 0.99 \\
\hline Heat exchanger effectiveness of condenser & 0.6 \\
\hline Heat exchanger effectiveness of evaporator & 0.86 \\
\hline Heat exchanger effectiveness of absorber & 0.94 \\
\hline
\end{tabular}

上記微分方程式および代数方程式によるモデルに対して 4 次のルンゲクッタ法およびニュートン-ラフソン法 を用いて動特性シミュレーションを行った.シミュレーションの時間ステップは 1 秒とした. 上記式において例 えば冷却水入口温度の変化に対する COP の変化は次のようになる. 冷却水入口温度 $T_{i}$ が下がると式(18)により $T_{o}$ も低下するが低下幅は $T_{i}$ より 小さいため, 式(19)により $Q_{a}$ が増加する. $Q_{a}$ が増加すると式(14)により $T_{a}$ が低下 し，これにより $\rho_{\mathrm{H} 2 \mathrm{Oa}}$ が増加するため式(13)により $G_{v a}$ が増加する. $G_{v a}$ が増加すると式(11)により $T_{v}$ が低下し， 式(18)により冷水出口温度 $T_{o}$ が低下する. 吸収式冷凍機を加熱する蒸気は冷水出口温度を $7^{\circ} \mathrm{C}$ 制御しているた め蒸気流量が絞られ, 結果として冷凍機の COP が上昇するが, 最終的には式(14)において $d T_{d} / d t=0$ となるところ で整定する. また冷凍機負荷すなわち冷水流量に対する COP の変化は次のようになる. 冷水流量が減少すると式 (19)により蒸発器での熱交換量 $Q$ が減少し, 式(11)により $T_{v}$ が低下する. $T_{v}$ が低下すると式(18)により冷水出口温 度 $T_{o}$ が低下し, 冷水出口温度 $7^{\circ} \mathrm{C}$ 制御を行っている蒸気流量が絞られ, 式(1)において $Q_{r 1}$ が減少し $T_{r 1}$ が低下する. これにより $G_{r 1 c}$ が減少し, 最終的に凝縮器から流入する凝縮水が減少する. 一方, $T_{v}$ が低下することで $\rho_{\mathrm{H} 2 \mathrm{Ov}}$ が 増加し式(13)により $G_{v a}$ が減少し，最終的には式(11)において $d T_{v} / d t=0$ となるところで整定する.

シミュレーション出力を図 3〜図 8 に示す. 図 3, 図 4 はモデルの静特性を評価するため各温度, 各負荷におけ る整定值を出力したものである. 図 3 は冷却水温度変化に対する 100\%負荷時の吸収式冷凍機の性能を示してお り, 冷水温度条件は戻り温度 $12^{\circ} \mathrm{C}$, 供給温度 $7^{\circ} \mathrm{C}$ あるる。図中, 比較として地域熱供給プラントから得られた吸

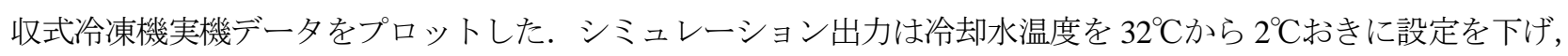
整定值をプロットし破線で結んだものである. 実機データは地域熱供給プラントで運転中の吸収式冷凍機の冷却 水入口温度を $27^{\circ} \mathrm{C}, 29^{\circ} \mathrm{C}, 32^{\circ} \mathrm{C}$ 変更し, それぞれ一定時間運転した後計測されたデ一タに基づくものである. 図 4 は吸収式冷凍機の各負荷に対する性能で, 冷水条件は図 3 と同じである。また図 3 と同様, 比較として吸収 式冷凍機の実機データをプロットした。 実機データは地域熱供給プラントで運転中の吸収式冷凍機の冷水流量を 100\%，90\%，50\%相当の流量に設定しそれぞれ一定時間運転した後計測されたデータに基づくものである.負荷 のばらつきは冷水流量や冷水温度の変動によるものである. 運転中の地域熱供給プラントからのデータ収集であ るため十分な整定状態が得られたわけではないが, 図 3, 図 4 ともシミュレーションは概ね実機データの平均的 な性能を表していることがわかる.

図 5〜図 8 は, 500USRT（約 6.3GJ/h）二重効用吸収式冷凍機の起動からの動特性で, 供給冷熱量, 蒸気流量, 冷水および冷却水出口温度に対するシミュレーション出力と実機データとの比較を示している. シミュレーショ ンでは, 冷水, 冷却水入口温度および流量を境界条件とし実機データを入力した. 図によればシミュレーション 
出力は吸収式冷凍機の実機応答を概ねよく表している．これにより蒸気流量制御の応答および熱容量による応答 遅れが支配的であり，内部の泠媒や溶液の輸送遅れ等は特に顕著ではないことがわかる.

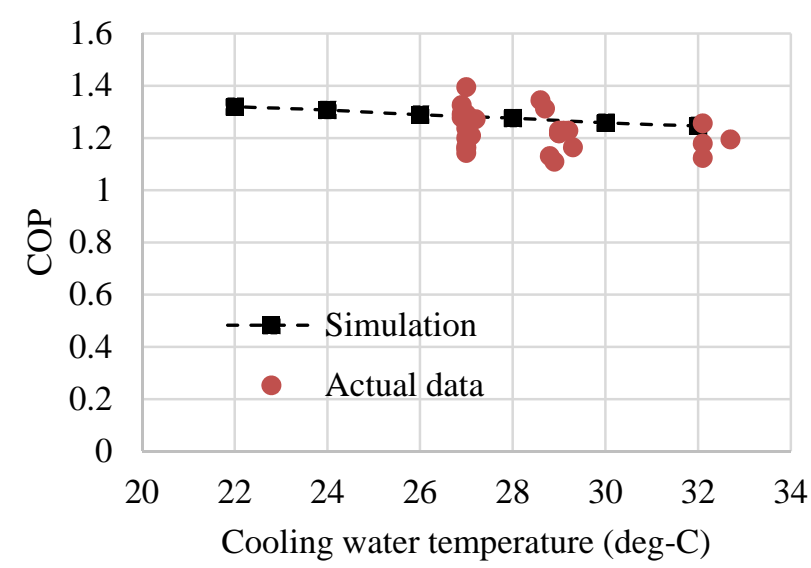

Fig. 3 Absorption chiller performance at $100 \%$ load under various cooling water temperatures.

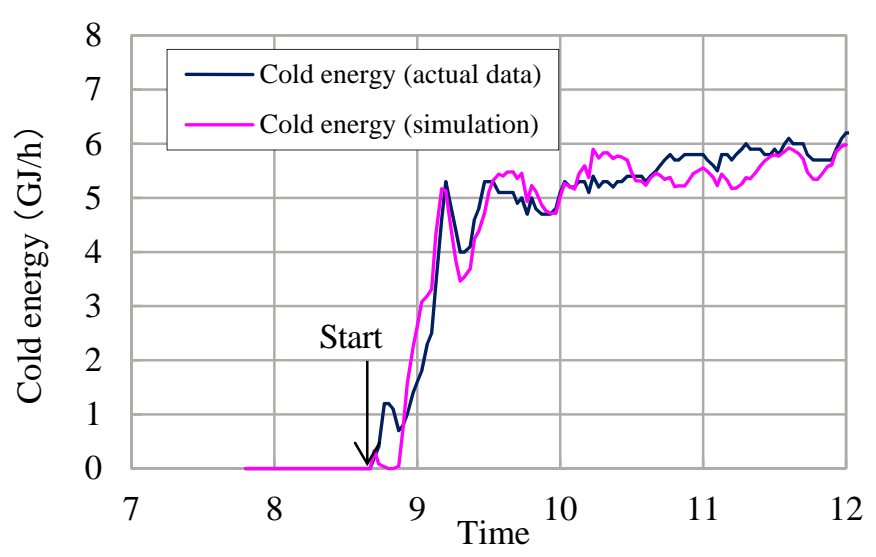

Fig. 5 Startup curve of absorption chiller (1).

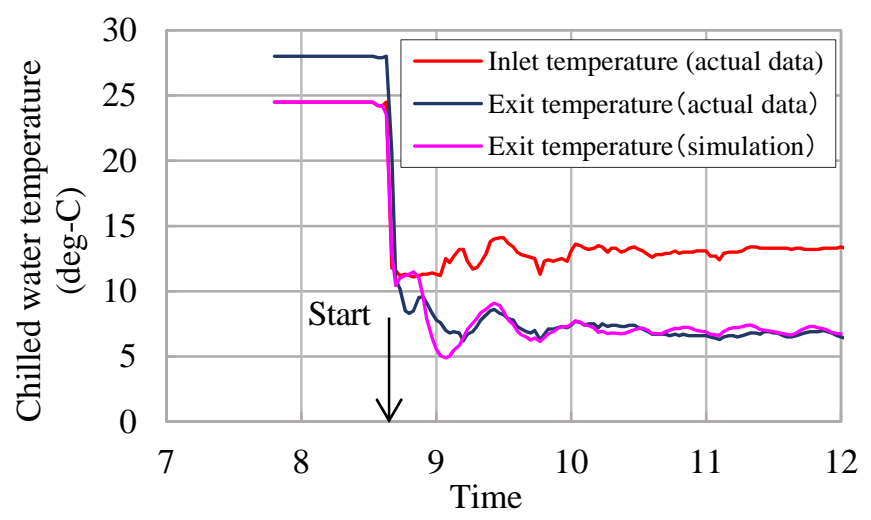

Fig. 7 Startup curve of absorption chiller (3).

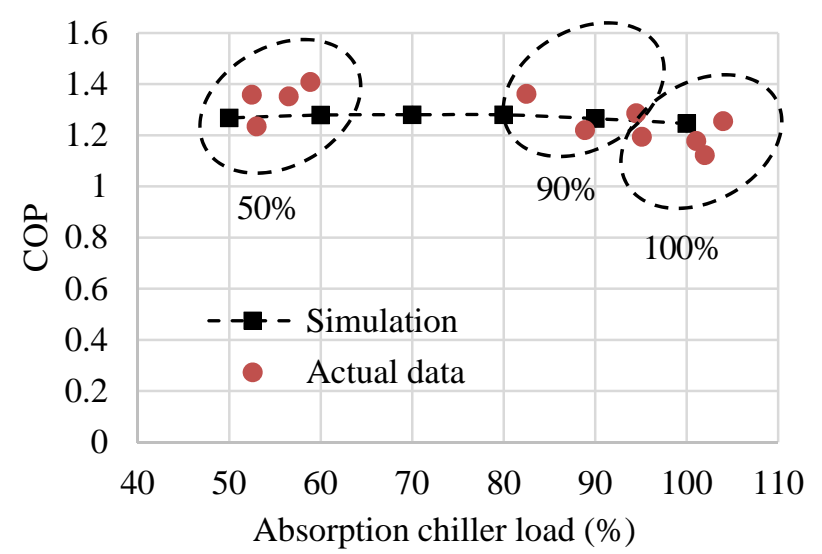

Fig. 4 Absorption chiller performance at 32 deg-C cooling water temperature under various loads.

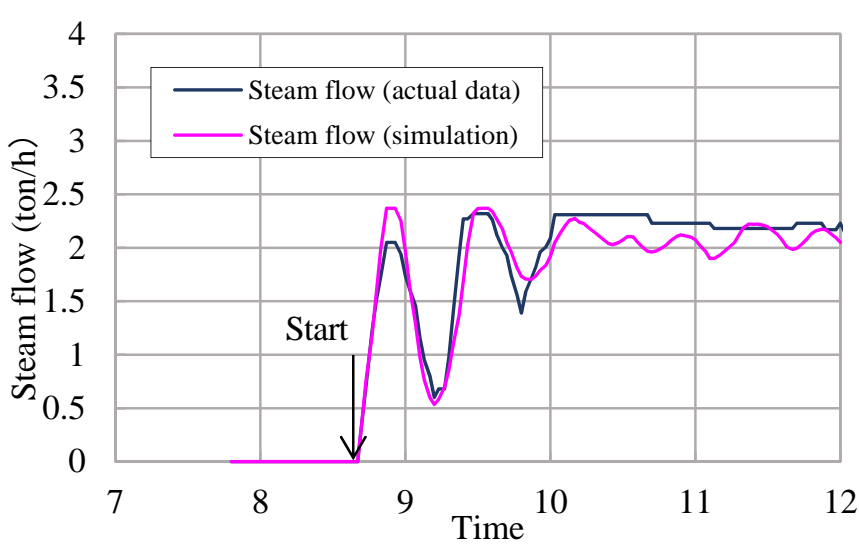

Fig. 6 Startup curve of absorption chiller (2).

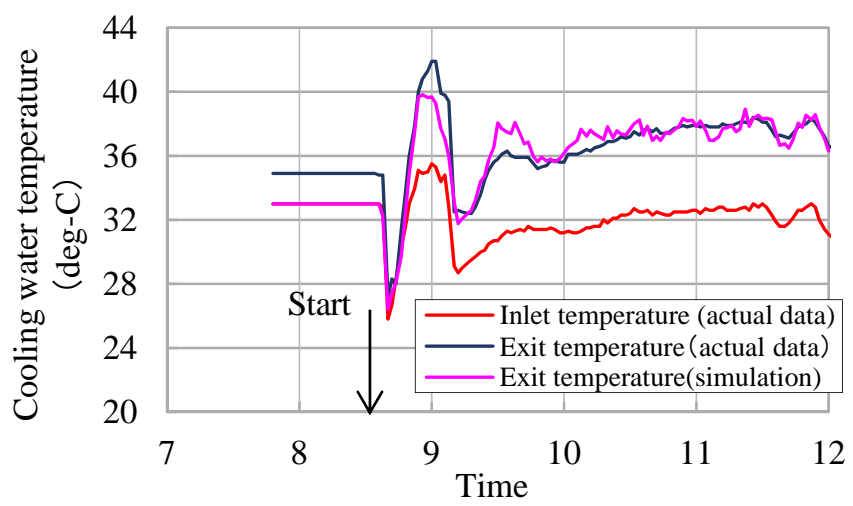

Fig. 8 Startup curve of absorption chiller (4).

\section{$3 \cdot 2$ 冷却塔モデル}

冷却塔は吸収式冷凍機からの排熱を大気中に放散することで泠却水温度を制御する機器であるが，吸収式冷凍 機と協調した運用を行うことでプラントのエネルギコスト削減にも役立つ重要な機器である(高田, 川原, 2003). モデル化の対象とした冷却塔は図 9 に示すようにファンで吸引された空気と冷却水とが直接接触する開放型機械 通風型冷却塔である. ファン 1 で吸引された空気は散水装置 2 から充填材 3 を伝わって流れ落ちる冷却水と熱交 換を行い, エリミネータ 4 で水滴が除去された後大気に放出される. 一方，冷却水は下部水槽 5 に集められたの ち吸収式冷凍機などの冷却対象機器に送水される。 


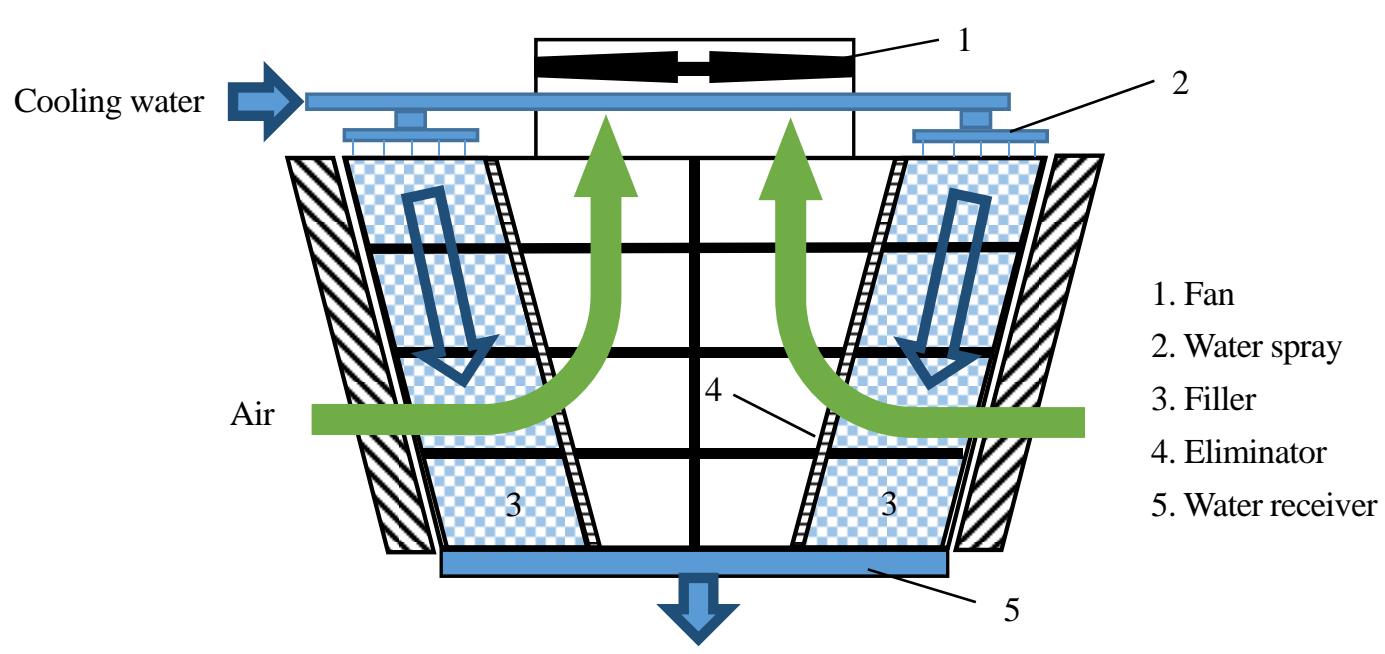

Fig. 9 Flow diagram of cooling tower.

冷却塔での熱収支, 物質収支を式(23)〜式(31)に示す. $T_{t}, C_{t}$ はそれぞれ冷却塔充填材の温度, 熱容量を表して いる.

冷却塔熱収支：

$$
C_{t} \frac{d T_{t}}{d t}=G_{g i} H_{g i}-G_{g o} H_{g o}+G_{w i} H_{w i}-G_{w o} H_{w o}-G_{d} r_{d}
$$

冷却塔物質収支：

$$
\begin{aligned}
& G_{g o}=G_{g i}+G_{d} \\
& G_{w o}=G_{w i}-G_{d}
\end{aligned}
$$

$G_{d}$ は冷却水の蒸発量, $r_{d}$ は蒸発潜熱で空気中の水蒸気分圧により以下の式で表される. なお $f_{1}, f_{2}$ はそれぞれ 蒸発潜熱, 飽和水蒸気圧力を求める 1999 日本機械学会蒸気表（日本機械学会, 1999）による関数である. また $P s i$ は入口空気の水蒸気分圧， $P_{s o}$ は出口空気の飽和水蒸気分圧を表している.

$$
\begin{aligned}
& G_{d}=K A\left(P_{s o}-P_{s i}\right) \\
& r_{d}=f_{1}\left(P_{s i}\right) \\
& P_{s i}=f_{2}\left(T_{g i}\right) \times \frac{R H}{100} \\
& P_{s o}=f_{2}\left(T_{g o}\right)
\end{aligned}
$$

冷却水と空気の熱交換は式(30)にて表される(高田, 川原, 2003). 冷却水と充填材の熱伝達は非常によく $T_{w o} \cong T_{t}$ と仮定すると式(31)により冷却塔空気出口温度が得られる.

$$
\begin{aligned}
& Q_{w g}=K_{a}\left(H_{w o}-H_{g i}\right) \\
& T_{g o}=T_{g i}+\frac{Q_{w g}}{G_{g i} C_{g}}
\end{aligned}
$$

上記の式において例えば空気流量の変化に対する冷却塔の動特性は次のようになる． $G_{g i}$ が減少すると式(23)に

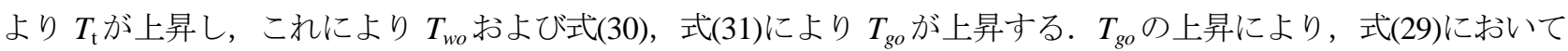
$P_{s o}$ が上昇し, 式(26)により $G_{d}$ が増加するが, 最終的に $d T_{t} d t=0$ となるところで整定する. シミュレーション出力 と冷却塔実機データとの比較を図 10 に示す.シミュレーション出力はファン速度強での空気流量を $100 \%$ とし, 10\%ずつ流量を削減したときの泠却水出入口の温度差をプロットし破線で結んだものである．実機データは，冷 却塔 1 台運転でファン速度強, 冷却塔 2 台運転でともにファン速度弱, 冷却塔 2 台運転で 1 台はファン速度弱, 1 台はファン停止とした 3 通りの運転状態において冷却水出入口温度を計測し，その温度差をプロットしたもの 
である. 冷却水入口温度の実機データ平均值は $32.5^{\circ} \mathrm{C}$, 冷却塔空気入口温度および相対湿度の実機データ平均值

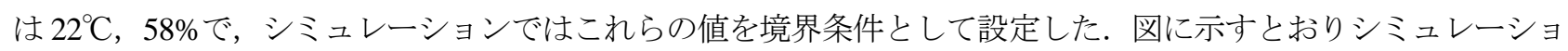
ンは実機の冷却塔性能を良く表していることがわかる.

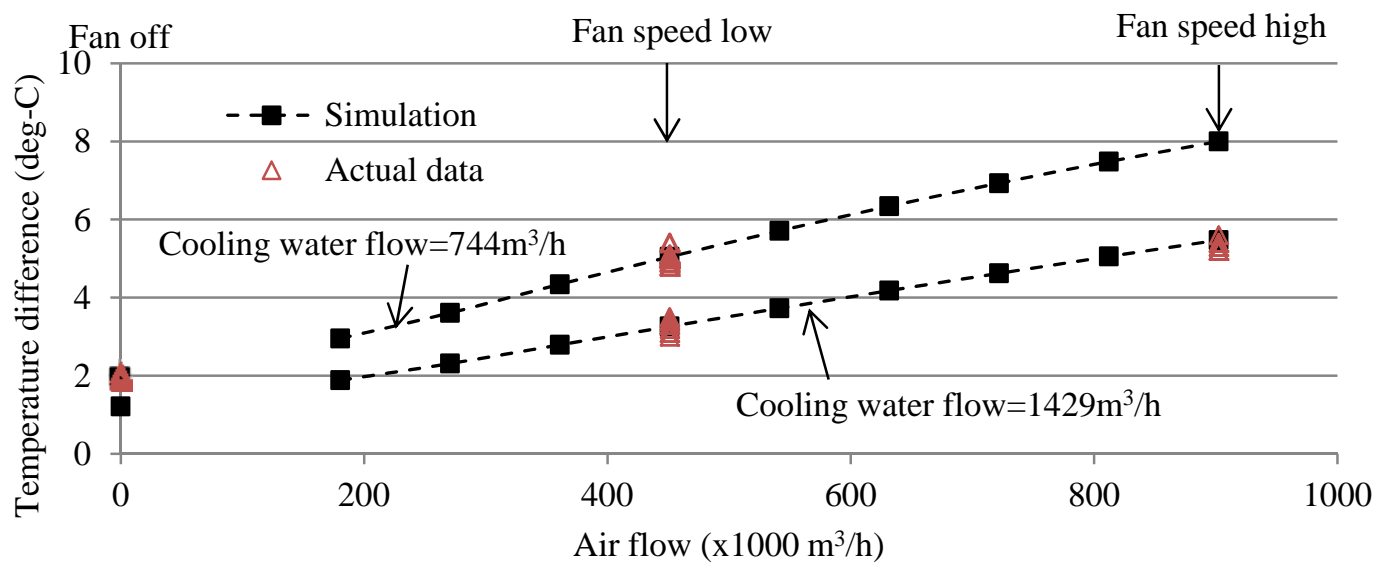

Fig.10 Cooling tower performance under various air flows and cooling water flows.

\section{4. 地域熱供給プラントへの適用}

\section{$4 \cdot 1$ 地域熱供給プラントの概要}

モデルの対象とした地域熱供給プラントは，ボイラ 5 台，二重効用吸収式冷凍機 4 台，温水熱交換器 3 台， タ 一ボ冷凍機 1 台, 冷却塔 4 台および蓄熱槽で構成されており, 需要家へ最大約 $40 \mathrm{GJ} / \mathrm{h}$ の冷熱および最大約 $30 \mathrm{GJ} / \mathrm{h}$ の温熱を供給している. プラントの概要を図 11 に示す. ボイラは都市ガスを燃料として蒸気を製造し蒸気ヘッダ を介して温水熱交換器および吸収式冷凍機に供給する. 温水熱交換器は蒸気との熱交換により約 $80^{\circ} \mathrm{C} の$ 温水を製 造し需要家へ温熱を供給する. 吸収式冷凍機は蒸気を熱源として約 $7^{\circ} \mathrm{C}$ 泠水を製造し需要家へ冷熱を供給する. またターボ冷凍機は深夜電力を利用して約 $5^{\circ} \mathrm{C}$ の冷水を蓄熱槽に蓄え, 蓄熱槽を介して需要家へ約 $7^{\circ} \mathrm{C}$ の冷熱を供 給する.

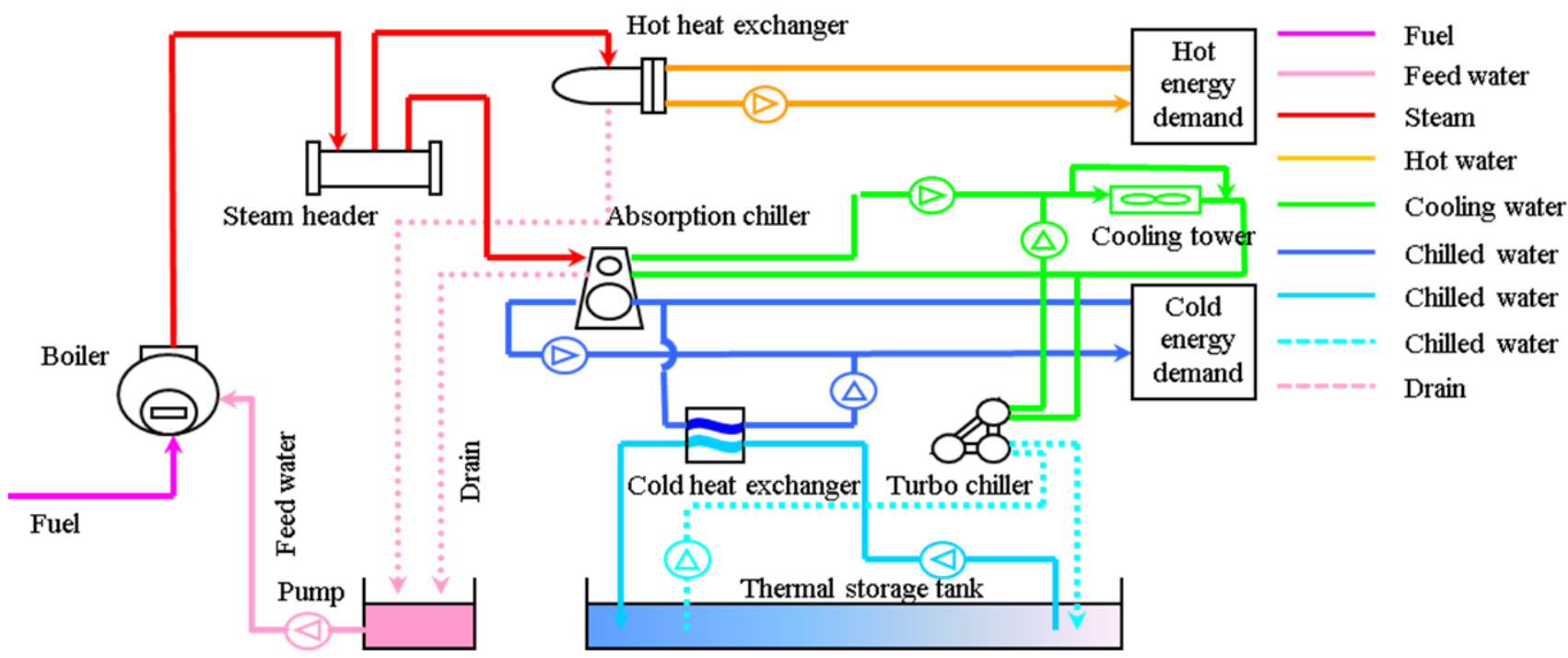

Fig. 11 System configuration of DHC plant.

図 12 は, ある夏期 1 日のプラントから需要家への冷熱供給量, 冷凍機, 蓄熱槽の運転状況を示している. 図に よれば朝 8 時から夜 22 時までは吸収式冷凍機と蓄熱槽により冷熱供給が行われ，22 時以降は吸収式冷凍機が停 止し蓄熱槽を介したターボ冷凍機による冷熱供給が行われていることがわかる. 図 13 は同日の温熱供給量を示し ている．夏期においてもわずかではあるが温熱が供給されていることがわかる. 


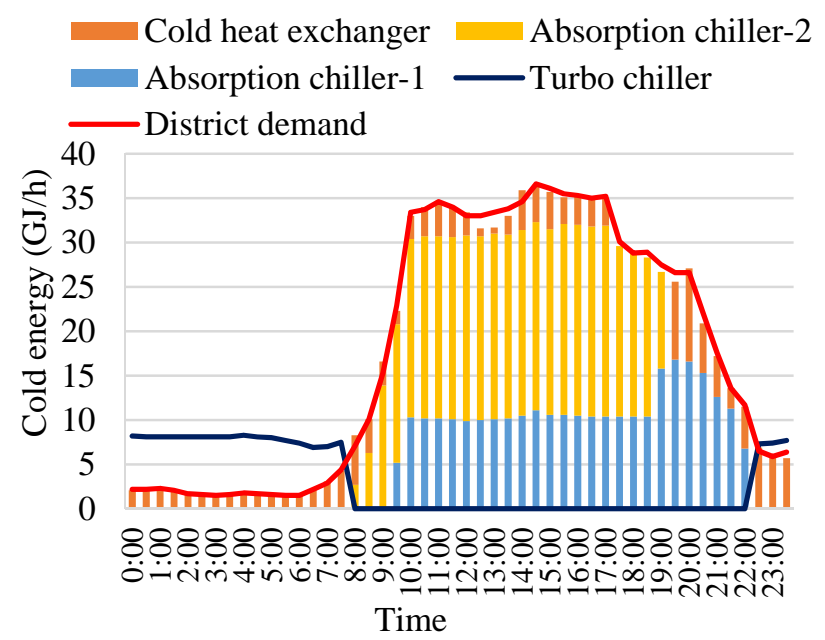

Fig. 12 Typical district cold energy demand and DHC plant operation in summer.

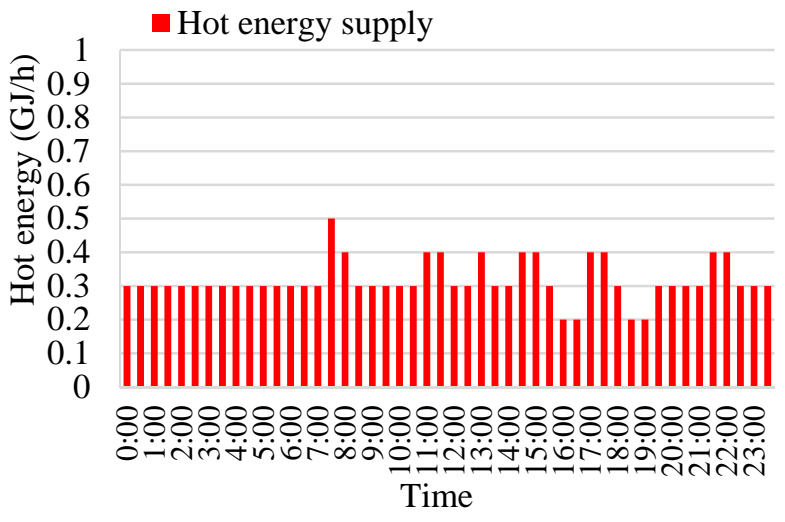

Fig. 13 Typical district hot energy demand in summer.

\section{$4 \cdot 2$ 地域熱供給プラントシミュレーション結果}

図 12 および図 13 に示した夏期 1 日の地域冷熱，温熱負荷に対してプラントシミュレーションを行った. シミ ユレーションでは, 表 2 に示寸ように地域冷熱負荷, 各冷凍機の冷水流量, 冷却水流量, 各熱源機器の運転/停 止状態を境界条件とし, 実機データを入力した. また冷水供給温度, 冷却水入口温度, ボイラ蒸気圧力は実機と 同様，それぞれ蒸気流量，冷却塔ファン速度，ボイラ然料流量による制御とした. 図 14, 図 15, 図 16 はプラン 卜のガス消費量, 電力消費量, 冷却水補給水量に対する 1 日の積算值を示している. ガスは需要家への温水供給, 冷水供給のためのボイラ然料として消費されるが，シミュレーション出力は 1 日を通して実機データを良く表し ている．電力はその消費量の約 25\%を占める冷却塔ファンが実機ではマニュアルで運転されていることから，シ ミュレーションでは吸収式冷凍機の冷却水入口温度が実機データと同程度となるようにファンの強弱切替を制御 することで対応した. 図 15 によれば前述した運転の相違等の理由により, シミュレーション出力は昼間実機デー タよりやや小さい值を示寸ものの合計ではほぼ同程度の值を示していることがわかる. 冷却水補給水量は, 吸収 式冷凍機が停止しターボ冷凍機の運転と切替わる 22 時〜 8時の梁夜時間帯において, シミュレーション出力では 毎時連続的に増加しているものの実機データでは断続的な増加となっている. しかし，吸収式冷凍機起動後の午 前 9 時の時点で積算量がほぼ一致していることを考慮すると, 実機の積算流量計では微小な流量増加が表示され ていないものと考えられる.

吸収式冷凍機の泠却水入口温度を上げると図 3 に示したように COP が低下して蒸気消費量が増えるため, ボイ ラでのガス消費量が増加する，一方，冷却塔では冷却水の蒸発量が増え補給水量が増加寸ると考えられるが，逆 にファンの消費電力は削減される可能性がある. 図 17 は吸収式冷凍機の冷却水入口温度を実機データ平均值より $\pm 2^{\circ} \mathrm{C}$ 変更したとき, プラントでのガス消費量, 電力消費量, 冷却水補給水量がどの程度変化するのかをシミュ レーションにより確認したものである. 吸収式冷凍機の冷却水入口温度を上げると, 前述したようにガス消費量, 補給水量は増加するものの, 電力消費量は減少する傾向を示すことが分かる. この結果にガス, 電力, 水の単価 を考慮すれば，設定值変更にともなう運転コスト変動の感度を把握することができ，運転コストを削減するよう 設定值を調整することができる. 本検討の定量的効果に関しては今後さらに検討を行い精度を検証していきたい. このようにシミュレータを用いればプラントの運用改善や設定值の変更によるガス, 電気, 水等消費量の変動を 事前に検討し，環境や負荷需要等の運転条件に最適なプラント運用や設定温度を確認することができる. 
Table 2 Condition of simulation.

\begin{tabular}{l|l|l}
\hline \hline \multicolumn{1}{c|}{ Items } & \multicolumn{1}{c}{ Conditions } & \multicolumn{1}{c}{ Set value (SV) } \\
\hline Chilled water exit temperature of absorption chiller & Controlled by steam flow & 7 deg-C \\
\hline Hot water exit temperature of hot heat exchanger & Controlled by steam flow & 80 deg-C \\
\hline Cooling water inlet temperature of absorption chiller & Controlled by cooling tower fan operation & 29 deg-C \\
\hline Cooling water inlet temperature of turbo chiller & Controlled by cooling tower fan operation & 29 deg-C \\
\hline Steam pressure & Controlled by boiler fuel flow & $0.8 \mathrm{MPa}$ \\
\hline Chilled water flow of absorption chiller & Input actual flow & - \\
\hline Cooling water flow of absorption chiller & Input actual flow & - \\
\hline District energy demand & Input actual district energy demand & - \\
\hline Equipment operation (start / stop) & Input actual start/stop operation & - \\
\hline
\end{tabular}

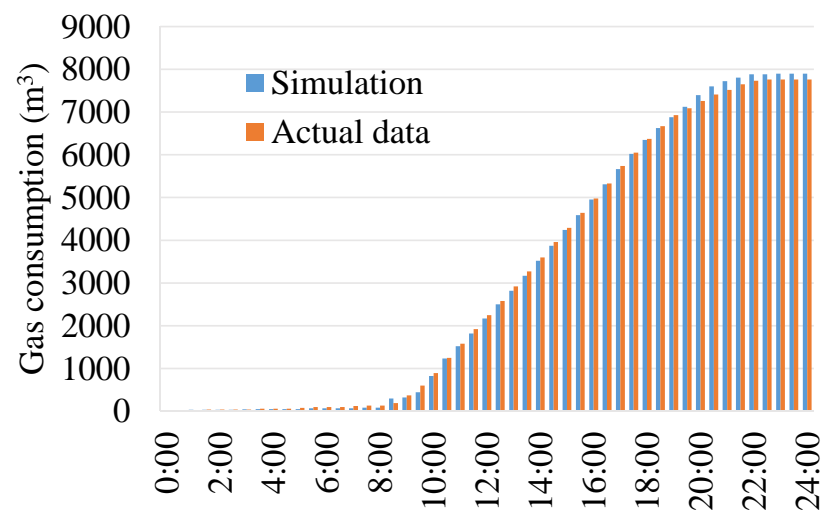

Time

Fig. 14 Cumulative gas consumption in a day.

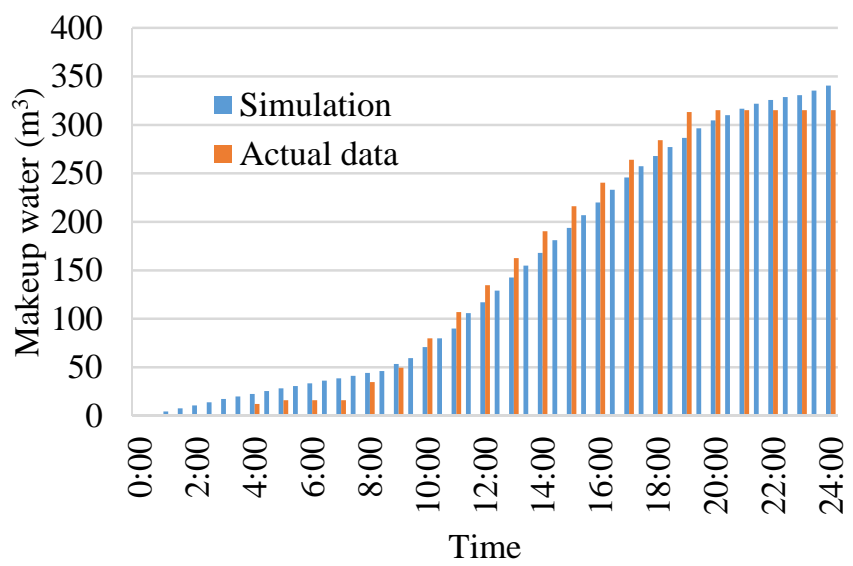

Fig. 16 Cumulative makeup water in a day.

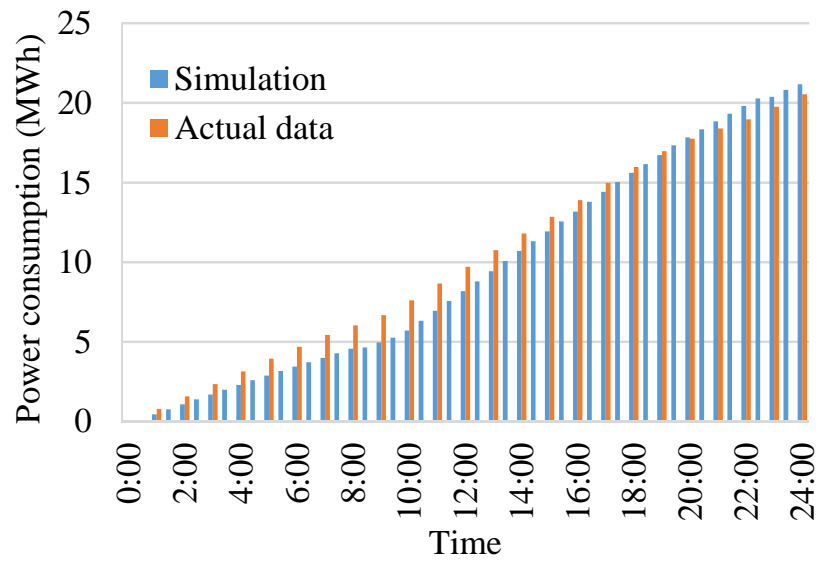

Fig. 15 Cumulative power consumption in a day.

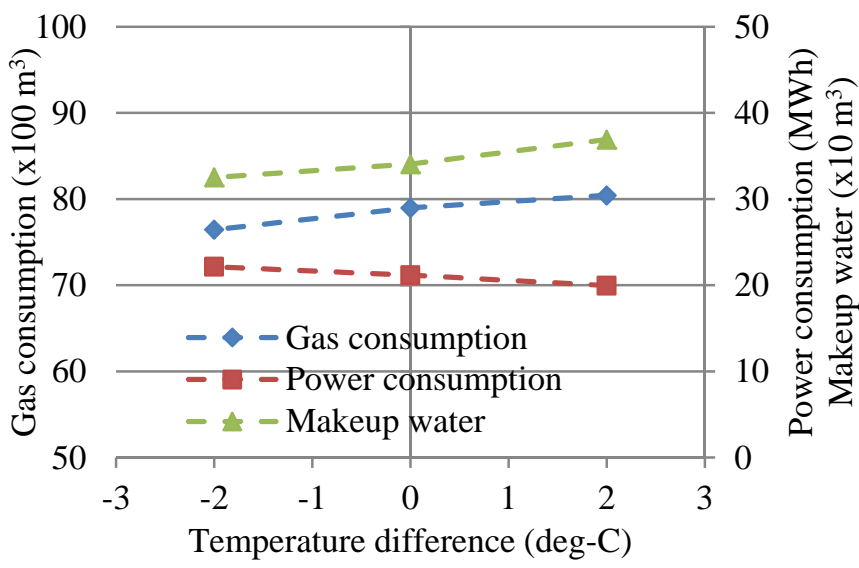

Fig. 17 Sensitivity analysis of gas, power and makeup water consumption for the cooling water temperature change, where 0 is average temperature of actual operation.

\section{5. 結 言}

地域熱供給プラントの運転，制御，システムに関して，省エネルギのための運用改善の検討やその効果の事前 確認等を目的として熱源プラント動特性シミュレータを開発した. シミュレーション出力とプラント運転データ を比較することによりモデルの妥当性を確認した．得られた結果を以下にまとめる. 
（1）起動時の応答遅れやそれによるエネルギ損失等を評価するために動特性をベースとした吸収式冷凍機モデ ルを開発した．開発したモデルに対して冷却水温度変化に対する性能，各負荷に対する性能に関してシミュ レーション出力と実機データとの比較を行った. 実機データとして運転中の地域熱供給プラントから収集さ れたデータを用いたが，シミュレーション出力は概ね実機データの平均的な性能を表していることを確認し た. また起動からの動特性に関しても, 供給冷熱量, 蒸気流量, 冷水および泠却水出口温度に関して比較を 行い, シミュレーション出力は実機の応答を良く表していることを確認した.

(2)冷却塔モデルを開発しシミュレーション出力と実機データとの比較を行った. 空気流量や泠却水流量の各值 に対してもシミュレーション出力は実機の冷却塔性能を良く表していることを確認した.

(3)開発した熱源機器モデルを適用して地域熱供給プラントシミュレータを構築し, ガス消費量, 電力消費量, 冷却水補給水量の夏期 1 日のシミュレーション出力と実機データとを比較した．ガス消費量に関して，シミ ユレーションは 1 日を通して実機データを良く表していることを確認した。電力消費量に関して, 実機冷却 塔がマニュアルで運転されている等の理由により, シミュレーション出力と実機データの応答がやや異なる 時間帯があるものの，合計ではほぼ同程度の值を示していることを確認した．また冷却水補給水量は，吸収 式冷凍機が停止しターボ冷凍機の運転と切替わる 22 時〜 8 時の深夜時間帯において, シミュレーション出力 と実機データの応答が異なっているが，吸収式冷凍機起動後の午前 9 時の時点では同程度の積算值を示して いることから，実機の積算流量計には微小な流量増加が表示されていないことが原因であると考えられる.

(4)吸収式冷凍機の冷却水入口温度を実機データ平均值より $\pm 2^{\circ} \mathrm{C}$ 変更してシミュレーションを行った. 冷却水 入口温度を上げるとガス消費量, 補給水量は増加するものの電力消費量は減少する傾向があることが分かっ た. この結果にガス, 電力, 水の単価を考慮すれば, 設定值変更にともなう運転コス卜変動の感度を把握す ることができるため, 最適なプラント運用や設定温度を事前に確認できる. なお設定值変更に対する定量的 な省エネルギ効果に関しては今後さらに検討を行い精度を検証していく予定である.

(5)開発した動特性シミュレータは, 熱容量や内部流体の蒸発, 凝縮等を考慮した熱源機器動特性モデルや蒸気 系統モデルを有しているためプラント内の圧力, 流量変動を検討でき, 将来の熱源機器増設や合理化, コー ジェネレーションなど近隣設備との接続や合理化運用などプラント改修時の健全性評価への適用が期待さ れる.

\section{文献}

Castera, K., Nerbollier, C., Brecq, G., Stabat, B. and Marchio, D., Dynamic modelling of a district cooling network with MODELICA, Proceedings of Building Simulation 2015 (2015), pp.1569-1576.

Evola, G., Le Pierres, N., Boudehenn, F., Papillon, P., Proposal and validation of a model for the dynamic simulation of a solar-assisted single-stage LiBr/water absorption chiller, International Journal of Refrigeration, Vol.36 (2013), pp.1015-1028.

藤田勇, 飛原英治, 臭化リチウム水溶液の水蒸気吸収における表面張力不安定に関する線形安定解析, 日本機械 学会論文集 B 編，Vol.63，No.613(1997), pp.161-169.

Funatsu, T., Hosaka, S., Morikawa, A., Akimaru, S., Kainuma, M., An evaluation of dynamic simulation via $1300^{\circ} \mathrm{C}$ class combined cycle plant, Proceedings of the 1999 International Joint Power Generation Conference \& Exposition and Icope99, PWR-Vol.34, Vol.2 (1999), pp.735-740.

日本熱物性学会, 新編熱物性ハンドブック (2008), pp.467-468.

Kohlenbach, P., and Ziegler, F., A dynamic simulation model for transient absorption chiller performance. part I: the model, International Journal of Refrigeration, Vol.31, Issue2 (2008a), pp.217-225.

Kohlenbach, P., and Ziegler, F., A dynamic simulation model for transient absorption chiller performance. part II: numerical results and experimental verification, International Journal of Refrigeration, Vol.31, Issue2 (2008b), pp.226-233.

Marc, O., Sinama, F., Praene, J.P., Lucas, F., Castaing-Lasvignottes, J., Dynamic modeling and experimental validation elements of a $30 \mathrm{~kW} \mathrm{LiBr/H2O} \mathrm{single} \mathrm{effect} \mathrm{absorption} \mathrm{chiller} \mathrm{for} \mathrm{solar} \mathrm{application,} \mathrm{Applied} \mathrm{Thermal} \mathrm{Engineering,}$ Vol.90 (2015), pp.980-993. 
Matsushima, H., Fujii, T., Komatsu, T., Nishiguchi, A., Dynamic simulation program with object-oriented formulation for absorption chillers (modelling, verification, and application to triple-effect absorption chiller), International Journal of Refrigeration, Vol.33, Issue2 (2010), pp.259-268.

経済産業省 資源エネルギー庁，平成 27 年度エネルギーに関する年次報告（エネルギー白書 2016）（2016），第 2 部, pp.149-151.

中原信生， 21 世紀の環境・エネルギとライフスタイルのありかた，空気調和・衛生工学会，Vol.75，No.1(2001), pp.1-9.

斎藤潔, 河合素直，西山教之，蒸気式二重効用吸収冷凍機の動特性解析，日本機械学会論文集 B 編，Vol.63， No.608(1997a), pp.269-276.

斎藤潔, 西山教之, 河合素直, 蒸気式二重効用吸収冷凍機の起動特性解析, 日本機械学会論文集 B 編, Vol.63, No.615(1997b), pp.201-209.

Shimoda, Y., Nagota, T., Isayama, N. and Mizuno, M., Verification of energy efficiency of district heating and cooling system using realistic parameters, Proceedings of Building Simulation 2005 (2005), pp.1123-1130.

高木康夫，岩㴊一徳，村山 大，船津徹也，下川兼司，空調システム評価のための熱原器モデルの開発，計測自 動制御学会論文誌, Vol.40, No.7 (2004), pp.762-769.

高田秋一, 吉川光雄, 吸収式冷凍機一蒸気吸収冷凍機とガス吸収冷温水機, 財団法人省エネルギーセンター (2004), pp.56-59.

高田秋一，川原孝七，クーリングタワー，財団法人省エネルギーセンター（2003）， pp.44-50， pp.165-169.

Tanaka, H. and Shimizu, T., Feasibility energy performance simulation of DHC system with gas engine driven chiller by using LCEM tool, Proceedings of Building Simulation 2011 (2011), pp.2186-2193.

日本機械学会, 1999 日本機械学会蒸気表 (1999).

$\mathrm{Xu}$, Y., Zhang, S. and Xiao, Y., Modeling the dynamic simulation and control of a single effect LiBr-H2O absorption chiller, Applied Thermal Engineering, Vol.107 (2016), pp.1183-1191.

\section{References}

Castera, K., Nerbollier, C., Brecq, G., Stabat, B. and Marchio, D., Dynamic modelling of a district cooling network with MODELICA, Proceedings of Building Simulation 2015 (2015), pp.1569-1576.

Evola, G., Le Pierres, N., Boudehenn, F., Papillon, P., Proposal and validation of a model for the dynamic simulation of a solar-assisted single-stage LiBr/water absorption chiller, International Journal of Refrigeration, Vol.36 (2013), pp.1015-1028.

Fujita, I. and Hihara, E., Liner stability analysis on surface tension-induced instability of LiBr aqueous solution absorbing water vapor, Transactions of the Japan Society of Mechanical Engineers, Series B, Vol.63, No.613 (1997), pp.161-169 (in Japanese).

Funatsu, T., Hosaka, S., Morikawa, A., Akimaru, S. and Kainuma, M., An evaluation of dynamic simulation via $1300^{\circ} \mathrm{C}$ class combined cycle plant, Proceedings of the 1999 International Joint Power Generation Conference \& Exposition and Icope99, PWR-Vol.34, Vol.2 (1999), pp.735-740.

Japan Society of Thermophysical Properties, Thermophysical properties handbook (2008), pp.467-468.

Kohlenbach, P., and Ziegler, F., A dynamic simulation model for transient absorption chiller performance. part I: the model, International Journal of Refrigeration, Vol.31, Issue2 (2008a), pp.217-225.

Kohlenbach, P., and Ziegler, F., A dynamic simulation model for transient absorption chiller performance. part II: numerical results and experimental verification, International Journal of Refrigeration, Vol.31, Issue2 (2008b), pp.226-233.

Marc, O., Sinama, F., Praene, J.P., Lucas, F., Castaing-Lasvignottes, J., Dynamic modeling and experimental validation elements of a $30 \mathrm{~kW} \mathrm{LiBr} / \mathrm{H} 2 \mathrm{O}$ single effect absorption chiller for solar application, Applied Thermal Engineering, Vol.90 (2015), pp.980-993. 
Matsushima, H., Fujii, T., Komatsu, T., Nishiguchi, A., Dynamic simulation program with object-oriented formulation for absorption chillers (modelling, verification, and application to triple-effect absorption chiller), International Journal of Refrigeration, Vol.33, Issue2 (2010), pp.259-268.

Ministry of Economy, Trade and Industry, Agency for Natural Resources and Energy, Annual report for energy usage in 2015, Part2 (2016), pp.149-151 (in Japanese).

Nakahara, N., The environment / energy and the life style of 21st. century, The society of heating, air-conditioning and sanitary engineers of Japan, Vol.75, No.1 (2001), pp.1-9 (in Japanese).

Saito, K., Kawai, S. and Nishiyama, N., Study on the dynamic characteristics of the double-effect absorption refrigerator driven by waste steam, Transactions of the Japan Society of Mechanical Engineers, Series B, Vol.63, No.608 (1997a), pp.269-276 (in Japanese).

Saito, K., Nishiyama, N. and Kawai, S., Study on the start-up characteristics of a double-effect absorption refrigerator driven by waste steam, Transactions of the Japan Society of Mechanical Engineers, Series B, Vol.63, No.615 (1997b), pp.201-209 (in Japanese).

Shimoda, Y., Nagota, T., Isayama, N. and Mizuno, M., Verification of energy efficiency of district heating and cooling system using realistic parameters, Proceedings of Building Simulation 2005 (2005), pp.1123-1130.

Takagi, Y., Iwabuchi, K., Murayama, D., Funatsu, T. and Shimokawa, K., Modelling of chillers for HVAC system evaluations, Transaction of the Society of Instrument and Control Engineers, Vol.40, No.7 (2004), pp.762-769 (in Japanese).

Takada, S. and Yoshikawa, M., Absorption chiller - Steam absorption chiller and gas absorption hot and cold dispenser, The energy conservation center, Japan (2004), pp.56-59 (in Japanese).

Takada, S. and Kawahara, K., Cooling tower, The energy conservation center, Japan (2003), pp.44-50, pp.165-169 (in Japanese).

Tanaka, H. and Shimizu, T., Feasibility energy performance simulation of DHC system with gas engine driven chiller by using LCEM tool, Proceedings of Building Simulation 2011 (2011), pp.2186-2193.

The Japan Society of Mechanical Engineers, 1999 JSME Steam tables (1999).

Xu, Y., Zhang, S. and Xiao, Y., Modeling the dynamic simulation and control of a single effect LiBr-H2O absorption chiller, Applied Thermal Engineering, Vol.107 (2016), pp.1183-1191. 